
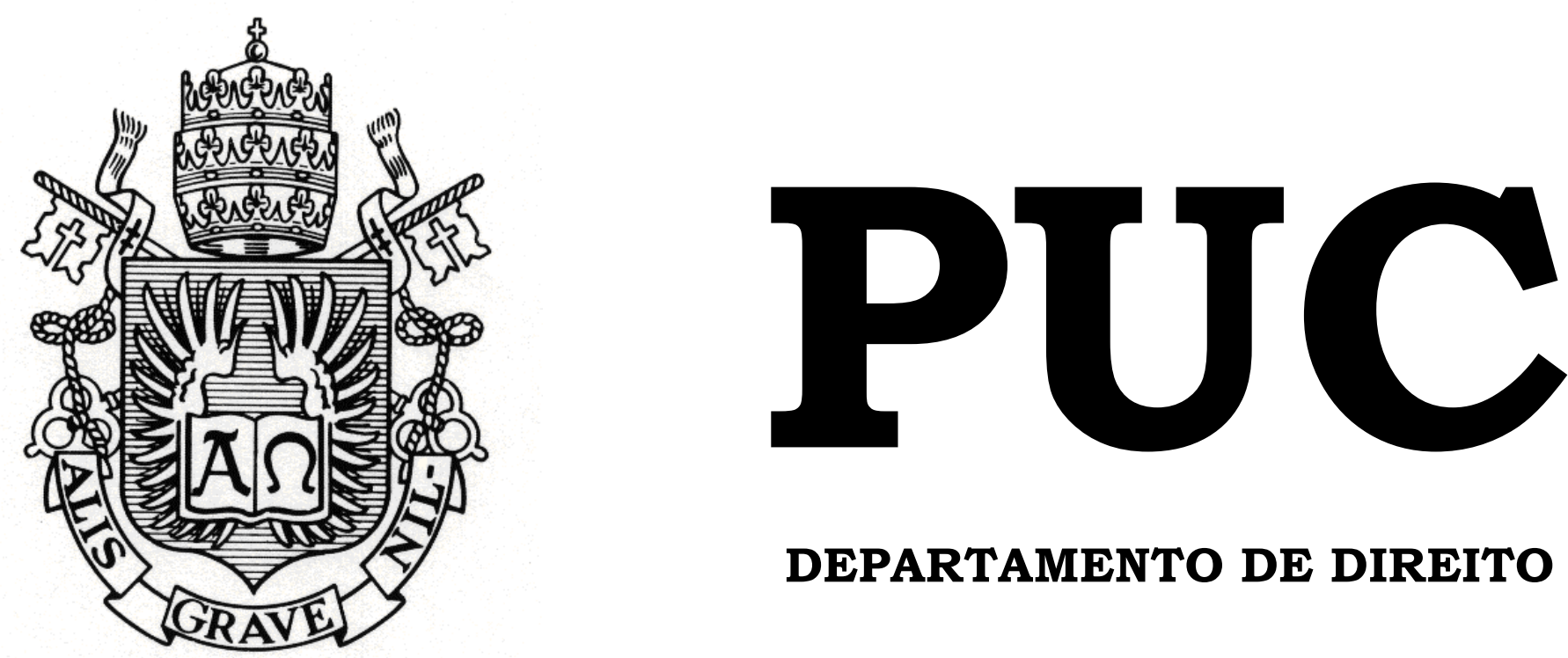

DEPARTAMENTO DE DIREITO

A ineficácia da aplicação da Função Social da Propriedade nos conflitos fundiários: os limites na garantia do Direito à Moradia

por

Júlia Rezende Toribio Dantas

ORIENTADOR: Adriano Pilatti

2019.2

PONTIFÍCIA UNIVERSIDADE CATÓLICA DO RIO DE JANEIRO

RUA MARQUÊS DE SÃO VICENTE, 225 - CEP 22453-900

RIO DE JANEIRO - BRASIL 


\section{A INEFICÁCIA DA APLICAÇÃO DA FUNÇÃO SOCIAL DA PROPRIEDADE NOS CONFLITOS FUNDIÁRIOS: OS LIMITES NA GARANTIA DO DIREITO À MORADIA}

por

JÚLIA REZENDE TORIBIO DANTAS

Monografia

apresentada

ao

Departamento de Direito da Pontifícia Universidade Católica do Rio de Janeiro (PUC-Rio) para a obtenção do Título de Bacharel em Direito.

Orientador: Adriano Pilatti 


\section{Agradecimentos}

A graduação pode ser qualquer coisa, menos fácil. São dramas, frustrações, alegrias, derrotas e vitórias. E como qualquer outra coisa da vida, não se passa por isso sozinha. A PUC é um espaço privilegiado por ser de fato uma Universidade. É um privilégio estudar na PUC - mesmo com todas as críticas e crises -, principalmente por ser uma universidade que busca integrar os cursos, bem como pesquisa e extensão. Assim, tive a oportunidade de trocar com muita gente que contribuiu para a realização deste trabalho e para a minha formação enquanto pessoa e estudante de direito.

Inicialmente, gostaria de agradecer o meu pai, minha mãe, meu irmão e meus avôs e avós por todo o apoio, do início ao fím. É imprescindível mencionar os professores Adriano Pilatti, Virgínia Totti, Mariana Trotta e Rafael Mendonça, que sempre estiveram ao meu lado e são grandes referências na busca por caminhos possíveis de mudança dentro do Direito. Agradeço também as amigas Paula, Sophia, Ana, Maira, Bebel, Camila, Jasmine, Laurinha, Laura, Aninha, Luíza, Vivi, Thais, Cid, Let, Ale e Bela, e os amigos Francisco, Felipe, Pedro, Johan, Joaquim, Chicão, Rayan, Erlie, Erik, Glauber, Nathan, João e Rodrigo por me acompanharem nessa caminhada.

Os amigos e colegas do Terras e Lutas e do NUTH foram fundamentais para encontrar meu lugar no Direito e para criar ambientes de acolhimento e luta coletiva. Os amigos da famosa vila merecem destaque também por aguentar minhas crises e sempre me apoiar - mesmo nas ideias mais fora da caixa. Muito obrigada por todas as trocas, experiências e aprendizados. 


\section{Resumo}

São inúmeros os debates sobre planejamento urbano e reforma agrária, no entanto, uma análise sobre a estrutura do Direito e da organização do Estado se demonstra urgente. A Função Social integra o meio jurídico enquanto princípio e elemento fundamental do direito de propriedade. No entanto, os contrastes sociais são evidentes na organização das cidades e do campo, na divisão do trabalho e no acesso ao direito. O contexto global de urbanização dos espaços e de ocupação cada vez mais acelerada dos centros urbanos gera diversos debates sobre a vida nas cidades. A precarização da vida nas metrópoles brasileiras exige soluções mais eficazes de concretização do Direito à Cidade.

Compreendendo tal contexto, o presente trabalho demonstra que as teorias e a práxis do direito não garantem o acesso universal a uma vida digna, sendo necessário romper com a dicotomia entre o público e o privado. Para isto, é apresentada a teoria do comum enquanto possibilidade de permear o direito com instrumentos de eficácia da Função Social e de garantia do Direito à Moradia, enquanto interesse comum. A concretização de direitos é um trabalho de co-operação de diversos setores da sociedade, sendo imprescindível entender que a estrutura jurídica atual não comporta as dinâmicas da realidade social.

Palavras-chave: Função Social da Propriedade; Direito à Moradia; Direito à Cidade; Comum. 


\section{Sumário}

Lista de Abreviações

Introdução 5

1.O Direito de Propriedade e a Função Social da Propriedade 7

1.1.O estatuto constitucional da propriedade no Brasil e a Função Social 7

1.2.Direito à Cidade, Função Social da Propriedade e o papel do Estado 9

1.2.1.O Direito à Moradia no Brasil

12

2.Os limites da aplicação da Função Social da Propriedade na garantia do $\begin{array}{ll}\text { Direito à Moradia } & 16\end{array}$

2.1.Prática Judicial 16

$\begin{array}{ll}\text { 2.2.Tutelas Coletivas } & 20\end{array}$

3.O paradigma da dicotomia entre público e privado 23

3.1.A Comissão Rodotá 23

3.2.A potência dos espaços públicos $\quad 24$

$\begin{array}{ll}\text { 3.3.A Teoria dos Comuns } & 28\end{array}$

3.3.1. As contribuições de Negri e Hardt 28

3.3.2. As contribuições de Dardot e Laval 29

3.3.3.O comum e a Função Social $\quad 30$

4.O comum como instrumento de garantia do Direito à Moradia 32

4.1.As experiências no grupo Terras e Lutas e no Núcleo de Terras e Habitação (NUTH) 32

4.1.1.As colaborações do Terras e Lutas 32

4.1.2. As colaborações do NUTH 33

4.2.Comum e a Moradia $\quad 34$

$\begin{array}{ll}\text { 5.Conclusão } & 38\end{array}$

$\begin{array}{ll}\text { Bibliografia } & 41\end{array}$ 


\section{Lista de Abreviações}

AEIS - Área de Especial Interesse Social

AMAHOR - Associação de Moradores do Horto

CRFB - Constituição da República Federativa do Brasil

CC - Código Civil

MST - Movimento dos Trabalhadores sem Terra

NPJ - Núcleo de Prática Jurídica

NUTH - Núcleo de Terras e Habitação da Defensoria Pública do Estado do Rio de Janeiro

ONU - Organização das Nações Unidas

PUC - Pontifícia Universidade Católica

Terras e Lutas - Direitos em Movimento: territórios e comunidades Grupo de extensão vinculado ao Núcleo de Estudos Constitucionais da PUC-Rio

ZEIS - Zona de Especial Interesse Social 


\section{Introdução}

As dinâmicas da vida urbanizada evidenciam desigualdades sociais que são reflexo de uma estrutura excludente. As cidades são organizadas em desacordo com os interesses locais, prevalecendo uma justificativa de desenvolvimento baseada nos parâmetros das cidades mercado ${ }^{l}$. Assim, os direitos fundamentais dos habitantes são secundários diante de um objetivo de "valorização" da cidade no cenário internacional.

O Estado e o Mercado atuam, de forma conjunta, moldando o espaço de acordo com interesses mútuos, que desenham os contrastes marcantes entre as classes e raças nas paisagens das cidades. Fruto de um processo histórico de segregação, a propriedade privada é um instrumento essencial para entender a atuação destas forças e os limites da resistência às insistentes formas de apropriação dos territórios e dos meios de vida.

A propriedade é a principal ferramenta para segregar e apropriar os territórios, culturas e modos de vida. A Função Social da Propriedade, então, é concebida como meio de tentar limitar os efeitos e consequências de uma interpretação absoluta deste instrumento.

No Brasil, entretanto, a propriedade privada é reforçada e respaldada por um histórico de proteção legal, cultural e social que dificultam a eficácia da Função Social e a relativização do direito de propriedade. Por mais que esteja, hoje, constitucionalizada a Função Social, sua aplicação ainda é pouco observada nos conflitos fundiários.

O Direito à Moradia, principalmente, em todos os direitos que compõem a noção de Direito à Cidade, têm sua eficácia limitada justamente pela não relativização do direito de propriedade e pelo não reconhecimento da função social como instrumento limitador deste direito ${ }^{2}$.

\footnotetext{
${ }^{1} \mathrm{O}$ termo destacado refere-se a um modelo mercantilizado de cidade, que busca tornar os espaços urbanos propícios para a expansão dos mercados, principalmente o mercado imobiliário. Esta perspectiva teórica está vastamente presente na bibliografia selecionada para a realização da presente monografia.

${ }^{2}$ As afirmações que introduzem o presente trabalho têm base em pesquisa de iniciação científica que estuda as dinâmicas das cidades nos tempos atuais. Tal pesquisa analisa o papel do Estado e do mercado na organização da cidade e as consequências para aqueles que estão excluídos das
} 
O objetivo do presente trabalho é evidenciar que a estrutura do direito, atualmente, não comporta a efetivação das conquistas codificadas na Constituição Federal de 1988. Cabe demonstrar, através do princípio da Função Social da Propriedade, paradigmas relativos à propriedade que precisam ser urgentemente atualizados. A ineficácia da aplicação desta conquista é fruto de uma estrutura legal engessada por uma atuação direcionada à manutenção da estrutura fundiária nas esferas legislativa e judiciária.

Esta perspectiva será introduzida por uma breve análise do conflito entre o direito de propriedade e a posse com função social. Será também analisado o papel do Estado na aplicação deste instituto, buscando compreender as obrigações e atuações dos poderes que compõem a máquina estatal.

Finalmente, será apresentada uma de tentativa romper uma barreira para a efetivação desse direito, no que tange o direito à moradia. Assim, para ampliar a possibilidade de efetivação de tal instituto, será apresentada uma possibilidade de ruptura com o paradigma da dicotomia público vs. privado. Esta apresentação será feita com base na teoria do comum, contribuições do direito romano e da Comissão Rodotà, buscando formas de efetivação do Direito à Cidade e da Função Social.

dinâmicas "formais" da cidade. Para mais informações consultar: DANTAS, Julia Rezende Toribio. Territórios Marginalizados, Direito à Moradia e o Comum. 2018. Disponível em: <http://www.puc-rio.br/pibic/relatorio_resumo2018/relatorios_pdf/ccs/DIR/DIR-

Julia_Rezende Toribio_Dantas.pdf $>$. 


\section{O Direito de Propriedade e a Função Social da Propriedade}

\subsection{O estatuto constitucional da propriedade no Brasil e a Função Social}

A propriedade privada é garantida, no Brasil, enquanto Direito Fundamental, desde a Carta Imperial de $1824^{3}$. Naquele momento, com a Revolução Francesa, a Revolução Industrial e a reorganização dos territórios, a propriedade passou a ser central nos debates do meio jurídico. Segundo os jusnaturalistas, a propriedade é direito natural, sendo cristalizado nos ordenamentos jurídicos como direito fundamental individual $^{4}$. A propriedade, na Constituição de 1988, é garantida no art. $5^{\circ}$, caput e inciso XXII. Assim, é um direito fundamental.

A partir de 1934, no entanto, inicia-se, no Brasil, um debate sobre a funcionalização da propriedade de acordo com o interesse social. ${ }^{5}$ Em 1946 a função social aparece no art. $147^{6}$. Na Constituição de 1967 a função social permanece como princípio da ordem econômica e social, mantendose o texto de 1934.

Em 1988 - no contexto da redemocratizaçãoe mobilização dos movimentos sociais -, a Função Social da Propriedade adquire status de direito e garantia individual, princípio de ordem econômica e indicação de conteúdo mínimo do direito de propriedade. Está inserida nas dinâmicas do mercado imobiliário - presente nos artigos 5, 170, II e III; 186 e 182 do

\footnotetext{
${ }^{3}$ BRASIL. Constituição (1824). Constituição Política do Império do Brasil. Rio de Janeiro, 1824. art. 179.

${ }^{4}$ OLIVEIRA, Álvaro Borges de; ROSSETTO, Danielle Cristina. A Propriedade como Direito (Não) Fundamental na Constituição Brasileira. Revista do Direito UNISC, Santa Cruz do Sul, n. 37, jan/jun. 2012.

5 TEPEDINO, Gustavo; SCHREIBER, Anderson. A Garantia Da Propriedade No Direito Brasileiro. Revista da Faculdade de Direito de Campos, Ano VI, No 6 - Junho de 2005.

6 "Art. 147. O uso da propriedade será condicionado ao bem estar social. A lei poderá, com observância do disposto no art. 141, § 16, promover a justa distribuição da propriedade com igual oportunidade para todos". (BRASIL. Constituição (1934). art. 147).
} 
diploma jurídico em questão. O direito de propriedade, por sua vez, passa a ser condicionado ao cumprimento da função social ${ }^{7}$.

“(...) não há como escapar ao sentido de que só garante o direito da propriedade, desde que este atenda sua função social. A própria Constituição dá consequência a isso quando autoriza a desapropriação, com pagamento mediante título, de propriedade que não cumpra sua função social ${ }^{8} . "$

Importante ressaltar que a função social não é um limite do direito da propriedade, mas uma condição. José Afonso da Silva aponta essa diferença, destacando que os limites da propriedade são as restrições, servidões e utilização de propriedade alheia e desapropriação. “(...) A função social se manifesta na própria configuração estrutural do direito de propriedade, pondo-se concretamente como elemento qualificante na predeterminação dos modos de aquisição, gozo e utilização dos bens ${ }^{9}$."

O constitucionalista entende que a propriedade é uma instituição múltipla, "em correlação com os diversos tipos de bens e titularidades ${ }^{10 \text { ", }}$ Com isso, o regime jurídico da propriedade, em todas as esferas, deve se submeter aos fundamentos e normas constitucionais - a função social.

A Constituição de 1988 também consagra a propriedade privada como um dos princípios da ordem econômica, conforme consta do art. 170. Nesse sentido, relativiza-se o conceito de propriedade, submetendo-o aos ditames da justiça social. Assim, afirma-se que só é legítima quando cumpre função social direcionada à justiça social. É nesse sentido que se questiona a propriedade privada enquanto direito fundamental individual ${ }^{11}$.

O princípio da função social é de aplicação imediata e

\footnotetext{
7 “Art. $5^{\circ}$ Todos são iguais perante a lei, sem distinção de qualquer natureza, garantindo-se aos brasileiros e aos estrangeiros residentes no País a inviolabilidade do direito à vida, à liberdade, à igualdade, à segurança e à propriedade, nos termos seguintes:

XXIII - a propriedade atenderá a sua função social”. (BRASIL. Constituição (1988), art. 5, XXIII).

${ }^{8}$ SILVA, José Afonso da. Curso de Direito Constitucional Positivo. 24. ed. São Paulo: Malheiros Editores Ltda., 2005. 924 p. ISBN 8574206326., p. 270.

${ }^{9}$ Ibid., p. 284.

${ }^{10}$ Ibid., p. 274.

${ }^{11}$ Ibid. 812 .
} 
"tem plena eficácia ${ }^{12}$, porque interfere com a estrutura e o conceito da propriedade, valendo como regra um novo regime jurídico desta, (...) ainda que nem a doutrina nem a jurisprudência tenham percebido o seu alcance, nem lhe dado aplicação adequada, como se nada tivesse mudado ${ }^{13}$."

José Isaac Pilati observa, então, que:

"É evidente a omissão quanto àqueles bens que não pertencem individualmente, mas a toda a coletividade, como é o caso do bem ambiental e dos direitos sociais previstos a partir do art. $6^{\circ}$ da CRFB, v.g. a saúde, que é direito de todos e um dever do Estado (art. 196).

A mesma omissão está presente no art. 92 do CC que, ao dispor sobre os bens reciprocamente considerados, deveria contemplar: bens principais, acessórios e sociais. (...)

Não se pode cogitar, portanto, de eficácia da função social da propriedade sem dar autonomia aos bens coletivos em que incide, e sem os devolver à legitima dona, a Sociedade (de quem foram usurpados pelo monopólio estatal, na configuração jurídica da propriedade moderna e seu Estado)". ${ }^{14}$

\subsection{Direito à Cidade, Função Social da Propriedade e o papel do Estado}

O Direito à Cidade trata da busca por soluções às questões inerentes à vida em uma sociedade urbanizada. É uma forma oposta à ideologia do consumo que se sustenta na luta pela efetivação e garantia dos direitos fundamentais e sociais, por uma vida digna para todos e todas na cidade.

\footnotetext{
${ }^{12}$ Eficácia enquanto capaz de produzir efeitos imediatamente. Conceito: "Norma constitucional efetiva seria aquela obedecida, seguida e aplicada, correspondendo aos fatores reais do poder que regem a sociedade. A efetividade das normas jurídicas resulta, em geral, de seu cumprimento espontâneo. Quando houver resistência, caberá ao jurista formular estruturas lógicas e prover mecanismos técnicos aptos a dar efetividade às normas jurídicas." MACHADO, Ivja Neves Rabelo. A eficácia dos direitos sociais Conteúdo Jurídico, Brasília-DF: 15 nov 2019. Disponível em: $\quad$ https://conteudojuridico.com.br/consulta/Artigos/42267/a-eficacia-dos-direitos-sociais. Acesso em: 15 nov 2019.

${ }^{13}$ Id., Aplicabilidade das normas constitucionais, $2^{\mathrm{a}}$ ed., p.134.

${ }^{14}$ PILATI, José Isaac. Propriedade e função social na pós-modernidade: função social e tutelas coletivas: contribuição do direito romano a um novo paradigma. Revista Sequência, $n$. 50 , p. 49-69, jul. 2005, p. 57.
} 
Henri Lefebvre ${ }^{15}$, partindo do pressuposto da urbanização completa da sociedade, delineia processos que culminam em uma sociedade onde determinados grupos vivem em situação de exclusão, enquanto outros grupos têm acesso aos direitos e garantias da vida na cidade. Para o autor, a cidade passou por três fases de constituição, quais sejam, a (i) política; (ii) comercial e (iii) industrial, que antecedem a sociedade urbana. Em cada uma das fases apresentadas, a posterior absorve as características da anterior, reorganizando o espaço para acolher os interesses predominantes do capital. A sociedade urbana é produto do processo de confronto destas três fases, o qual o autor denomina de implosão-explosão. Implosão é a capacidade cada vez maior que as cidades têm de aglutinar fluxos de pessoas, capital e mercadorias. Explosão, por outro lado, trata-se da capacidade de expansão cada vez maior das dinâmicas da vida urbana para locais distantes dos centros urbanos.

O autor trabalha com o conceito de Revolução Urbana, que é o conjunto de transformações que buscam a superação das problemáticas inerentes à vida na cidade. A segregação espacial, a exploração do trabalho e as desigualdades sociais são algumas delas.

No debate sobre o Direito à Cidade, cumpre ressaltar o conceito de Direitos da Cidade, que, “(...) é aquele que se preocupa com a integração sócio-espacial (enxerga a cidade como um bem coletivo e, portanto, um direito difuso de seus habitantes)". ${ }^{16}$ Para o jurista Daniel Almeida de Oliveira, os indivíduos, ao abrirem mão de liberdades, têm direitos subjetivos da garantia aos direitos fundamentais. Para ele,

“justamente por querer não apenas regular situações jurídicas para resguardar interesses, mas principalmente induzir relações jurídicas e sociais, bem como atividades sociais(...), fica dependente de outros conhecimentos humanos, de outras ciências humanas, como a economia,

\footnotetext{
${ }^{15}$ LEFEBVRE, Henri. A Revolução Urbana. Belo Horizonte: EDUFMG, 2004.

Id. O Direito à Cidade. $1^{\mathrm{a}}$ ed. São Paulo: Moraes, 1991.

${ }^{16}$ OLIVEIRA, Daniel Almeida de. O Direito da Cidade no Direito e nas questões sociais: limites, possibilidades e paradigmas. In: Coutinho, Ronaldo do Livramento; Bonizzato, Luigi. (Org.). Direito da Cidade: novas concepções sobre as relações jurídicas no espaço social urbano.. led.Rio de Janeiro: Lumen Juris Editora, 2007, v. 1, p.79.
} 
sociologia e política. (...) Nota-se, já aqui, que no Direito da Cidade, indubitavelmente, num contexto globalizado, o Estado perde, em larga escala, o seu poder de veto, tendo que, muitas vezes, tornar-se um mediador ou um indutor."17

O Direito à Cidade busca a efetivação dos direitos fundamentais e dos direitos da cidade, quais sejam o direito à moradia, saúde, educação, transporte, saneamento básico, entre outros.

Dada à interdisciplinaridade do tema, importante destacar que o espaço manifesta as relações sociais, ao mesmo tempo em que reage sobre elas. Assim, o espaço é produtor e produto social ${ }^{18}$. Isto quer dizer que as funções dos territórios são dinâmicas e afetadas, de forma dialética, por diferentes atores tanto de ordem próxima - grupos locais -, quanto de ordem distante - geralmente o poder estatal, empresarial e institucional.

Destarte, no que tange o direito à moradia, a Função Social da Propriedade é uma importante ferramenta na tentativa de efetivação do acesso ao direito à moradia, bem como aos demais direitos inerentes à vida no espaço urbano.

No contexto de concretização do Direito à Cidade e mesmo da Função Social da Propriedade, o Estado exerce um papel contraditório. O Estado é, constitucionalmente, responsável pela garantia e efetivação destes direitos. Não obstante, é observada uma tendência a atender às demandas do mercado em detrimento dos interesses das populações locais.

A tendência de que se fala é observada, na administração, na falta de políticas públicas direcionadas às populações excluídas das dinâmicas da cidade e também na flexibilidade dos direitos trabalhistas; na manutenção do trabalho informal; nos investimentos em empreendimentos que não atendem demandas locais; na privatização de empresas estatais que vulnerabilizam os funcionários, bem como num planejamento da cidade que atende principalmente o mercado imobiliário ${ }^{19}$.

\footnotetext{
${ }^{17}$ OLIVEIRA, Daniel Almeida de. Op. cit, p.79.

${ }^{18}$ LEFEBVRE, Henri. A Revolução Urbana. Belo Horizonte: EDUFMG, 2004.

${ }^{19}$ Sobre o tema, ver: FERNANDES, Edésio. A nova ordem jurídico-urbanística no Brasil. In: FERNANDES, Edésio; ALFONSIN, Betânia. Direito urbanístico: estudos brasileiros e
} 
Outrossim, o sistema judiciário tende a não reconhecer a Função Social da Propriedade enquanto princípio ou instrumento de garantia ao direito à moradia. Isto porque tende a predominar a argumentação da alegada má-fé dos posseiros em confronto com a suposta boa-fé dos proprietários. Ainda, há políticas de racismo ambiental que afetam diretamente a segurança da posse das moradias informais ${ }^{20}$.

É imprescindível reconhecer os avanços constitucionais e legislativos relativos à Propriedade e ao Direito à Cidade. No entanto, o papel do Estado nos conflitos fundiários não se demonstra eficaz no que tange a garantia do Direito à Moradia.

“(...) Quanto mais caracterizadamente uma lei protege os interesses populares e emergentes, maior é a probabilidade de que ela não seja aplicada. Sendo assim, a luta democrática pelo direito deve ser, no nosso país, uma luta pela aplicação do direito vigente, tanto quanto uma luta pela mudança do direito." 21

\subsubsection{O Direito à Moradia no Brasil}

O Direito à Moradia foi incorporado à CRFB de 1988, por meio da Emenda Constitucional n. 26/2000. O art. $6^{\circ}$ integra o capítulo dos Direitos e Garantias Fundamentais e eleva tal direito ao status de Direito Social Universal. $\mathrm{O}$ direito à moradia é transversal aos direitos na cidade, sendo sua disputa, uma disputa por existência. Com a globalização e contínua urbanização do espaço, os debates sobre a moradia tomaram uma dimensão internacional. Tal direito é garantido pela Declaração Universal de Direitos

\footnotetext{
internacionais. Belo Horizonte: Del Rey, 2006 e SAULE JÚNIOR, Nelson. O Direito à Cidade como paradigma de cidades justas, democráticas e sustentáveis. In: Roberto B. Dias da Silva. (Org.). Direito Constitucional Temas Atuais. 1ed. São Paulo: Editora Método, 2007, v. 01, p. 169210.

${ }^{20}$ GUIMARÃES, Virgínia Totti; PINTO, Paula Máximo de Barros. Racismo ambiental e aplicação diferenciada das normas ambientais: uma aproximação necessária entre os casos da Comunidade do Horto Florestal e do Condomínio Canto e Mello (Gávea/RJ), 16 p. Rio de Janeiro, 2018.

${ }^{21}$ OLIVEIRA, Daniel Almeida de. Op. Cit., p. 178.
} 
Humanos da $\mathrm{ONU}^{22}$ e reconhecido no Pacto Internacional dos Direitos Econômicos, Sociais e Culturais ${ }^{23}$.

A conceituação de moradia, de acordo com esses debates, não se resume à mera garantia de um espaço físico para firmar moradia, compreendendo que há outros elementos que são essenciais à garantia dos direitos fundamentais. É importante o acesso a serviços básicos, condições dignas de habitabilidade, segurança da posse e identidade territorial, principalmente.

No Brasil, no entanto, como já mencionado, a luta pelo Direito à Moradia encontra diversos entraves (que serão debatidos mais adiante), criando um cenário de desigualdades gritantes nas paisagens das cidades. Para ilustrar a situação da moradia no país, importante trazer conceito de Déficit Habitacional:

"O conceito de déficit habitacional (...) está ligado diretamente às deficiências do estoque de moradias. Engloba aquelas sem condições de serem habitadas em razão da precariedade das construções ou do desgaste da estrutura física e que por isso devem ser repostas. Inclui ainda a necessidade de incremento do estoque, em função da coabitação familiar forçada (famílias que pretendem constituir um domicílio unifamiliar), dos moradores de baixa renda com dificuldades de pagar aluguel nas áreas urbanas e dos que vivem em casas e apartamentos alugados com grande densidade. Inclui-se ainda nessa rubrica a moradia em imóveis e locais com fins não residenciais. O déficit habitacional pode ser entendido, portanto, como déficit por reposição de estoque e déficit por incremento de estoque ${ }^{24}$."

A Fundação João Pinheiro fornece estes dados - urbanos e rurais -

\footnotetext{
${ }^{22}$ Declaração Universal de Direitos Humanos da ONU. Art. XXV. Todo ser humano tem direito a um padrão de vida capaz de assegurar-lhe, e a sua família, saúde e bem-estar, inclusive alimentação, vestuário, habitação, cuidados médicos e os serviços sociais indispensáveis, e direito à segurança em caso de desemprego, doença, invalidez, viuvez, velhice ou outros casos de perda dos meios de subsistência em circunstâncias fora de seu controle.

${ }^{23}$ Pacto Internacional dos Direitos Econômicos Sociais e Culturais. Art. 11. §1. Os Estados Partes do presente Pacto reconhecem o direito de toda pessoa a um nível de vida adequado para si próprio e sua família, inclusive à alimentação, vestimenta e moradia adequadas, assim como a uma melhoria contínua de suas condições de vida. Os Estados Partes tomarão medidas apropriadas para assegurar a consecução desse direito, reconhecendo, nesse sentido, a importância essencial da cooperação internacional fundada no livre consentimento.

24 FUNDAÇÃO JOÃO PINHEIRO. Déficit Habitacional no Brasil 2015. Estatística \& Informações 6: Demografia e Indicadores Sociais. Belo Horizonte, 2018., p. 20.
} 
do ano de 2015 por situação de domicílio, segundo regiões geográficas do Brasil. O déficit habitacional urbano da região norte chega quase $80 \%$, na região nordeste é em torno de $70 \%$ e nas regiões sudeste, sul e centro-oeste, ultrapassam $90 \%{ }^{25}$.

"Do total do déficit habitacional em 2015, 39\% localiza-se na região Sudeste, o que corresponde a 2,482 milhões de unidades. Em seguida vem a região Nordeste, com 1,971 milhões de moradias estimadas como déficit, o que corresponde a $31 \%$ do total. ${ }^{26,}$

Um instrumento importante na criação de prerrogativas de participação da cidade e de regularização fundiária é o Estatuto da Cidade ${ }^{27}$. A partir deste Estatuto, são instituídas as Áreas de Especial Interesse Social, bem como se observa o fenômeno da funcionalização dos direitos, principalmente do direito de propriedade, como destaca Augusto Werneck $^{28}$. O autor aponta os potenciais e críticas às AEIS:

“(...) a regulação setorial em zonas ou áreas de especial interesse social, realizada nos termos da gestão democrática da cidade, faria surgir a prática democrática permanente de conselhos eleitos para decidir o uso e a ocupação do solo e a formulação do zoneamento, o licenciamento de atividades econômicas e a prioridade nas intervenções do poder público na região, dinamizando o instituto das ZEIS ou AEIS (...). [há] problemas pragmáticos na adoção do sistema, como o controle centralizado dos ordenamentos setoriais e os limites de delegação legislativa toleráveis. Outra preocupação é de dotar-se de meios orçamentários e financeiros para a organização dos espaços e elevação dos níveis gerais de desenvolvimento humano e a coordenação das políticas públicas que venham a ser efetivadas naquela ZEIS ou AEIS. Aqui, cabe destacar toda a tradição de pesquisas e trabalhos científicos (...) que trazem a perspectiva da autonomia das comunidades populares. ${ }^{29,}$

A Lei 13.465/2017 também trata da regularização fundiária, se

\footnotetext{
${ }^{25}$ Ibid., p. 34.

${ }^{26}$ Ibid., p. 31.

27 BRASIL. Estatuto da Cidade: Lei 10.257/2001 que estabelece diretrizes gerais da política urbana. Brasília, Câmara dos Deputados, 2001, 1a Edição.

${ }^{28}$ WERNECK, Augusto. Função Social da Cidade. Plano Diretor e Favelas. A Regulação Setorial nas Comunidades Populares e a Gestão Democrática da Cidade. In:__ Direito da Cidade: Novas concepções sobre as relações jurídicas no espaço social urbano. Rio de Janeiro: Lumen Juris, 2007.

${ }^{29}$ Ibid., p 123-124.
} 
demonstrando como uma barreira à efetivação deste direito por criar obstáculos para a realização de políticas de regularização fundiária. Estas políticas são essenciais para assegurar os elementos ${ }^{30}$ que compõem o conceito de moradia. Ainda, a referida lei privilegia a titulação individual da propriedade, enfraquecendo os institutos de legitimação coletiva da $\operatorname{posse}^{31}$.

O título de propriedade não deve prevalecer em detrimento do reconhecimento da posse com função social. Assim, essencial observar a relevância dos instrumentos coletivos de legitimação da posse no debate sobre a moradia. São essenciais para impedir a reconcentração fundiária e garantir o acesso às políticas de crédito estatais ${ }^{32}$.

No entanto, mesmo sendo elemento que compõe o conceito de propriedade, a função social ainda não é capaz de garantir a efetividade dos instrumentos de garantia do acesso à moradia. Nesse sentido, cabe analisar os limites estruturais da garantia do direito a uma moradia digna e de acesso universal.

\footnotetext{
${ }^{30}$ Acesso a serviços básicos, condições dignas de habitabilidade, segurança da posse e identidade territorial.

${ }^{31}$ MENDONÇA, Rafael da Mota. A Transferência de Propriedade como Novo Modelo da Regularização Fundiária: a Legitimação Fundiária e a Legitimação de Posse. In: FERNANDES, Arícia Correias (Org.). Direito da Regularização Fundiária Urbana Sustentável. Juiz de Fora: Editar, 2018. P. 259-284.

${ }^{32}$ Dois pontos essenciais das propriedades coletivas é a divisão dos ônus. Quando a propriedade regularizada se torna individual, há uma tendência à cessão da posse pelos ônus excessivos do proprietário e aumento dos preços dos serviços básicos locais.
} 


\section{Os limites da aplicação da Função Social da Propriedade na garantia do Direito à Moradia}

Nas sociedades urbanas há camadas sociais em condições de extrema precarização de todos os meios de vida. ${ }^{33}$ São essas camadas sociais que o Direito à Cidade e a Função Social buscam atender.

A propriedade privada tem proteções jurídicas, sociais e culturais. Os limites ao direito de propriedade se demonstram complexos de ser aplicados por excessos do poder de propriedade. Mesmo com a introdução da função social nos ordenamentos jurídicos, o instituto da propriedade, na prática, parece permanecer como direito fundamental individual, sem observância do condicionamento ao atendimento da função social. Os conflitos fundiários judicializados ou submetidos à Administração Pública ainda não recebem a tutela de todas as proteções jurídicas resultantes do Princípio da Função Social. Nesse sentido, cabe uma análise mais densa dos limites da aplicação deste princípio.

\subsection{Prática Judicial}

O debate sobre a eficácia do princípio e dos institutos jurídicos em questão torna necessária uma análise sobre a práxis do poder judiciário nos conflitos fundiários. João Maurício Martins de $\mathrm{Abreu}^{34}$ realizou uma pesquisa sobre a prática judicial e o discurso normativo vigente que servirá como base para evidenciar a não aplicação do princípio e da legislação a que se refere.

\footnotetext{
${ }^{33}$ HAESBAERT, Rogério. Viver no Limite: território e multi/transterritorialidade em tempos de in-segurança e contenção. Rio de Janeiro: Bertrand Brasil, 2014.

${ }^{34} \mathrm{ABREU}$, João Maurício Martins de. A moradia informal no banco dos réus: discurso normativo e prática judicial. Revista de Direito FGV, São Paulo, 2011, p. 391-415.
} 
Tal pesquisa tem como parâmetro justamente os assentamentos informais - loteamentos urbanos irregulares ou clandestinos, favelas e ocupações de imóveis privados ou públicos. Para o autor,

"é aí que a moradia, como direito, vive seu drama social e coletivizado; é aí que os cidadãos encontram no direito à moradia sua única trincheira jurídica contra despejos forçados, enquanto os moradores-proprietários e os moradores-locadores de seus imóveis já têm amparo idôneo no instituto da propriedade e do inquilinato ${ }^{35}$."

Ao introduzir sua pesquisa, Martins de Abreu apresenta um pressuposto que ampara a afirmação citada e enfatiza a importância da descriminalização dos assentamentos informais e do reconhecimento do princípio da função social pelo judiciário e pela administração pública. Ele afirma que:

“(...) o homem e a mulher têm o direito, inerente à própria vida, de ocupar um lugar no espaço e firmar uma relação com ele; de que, normalmente, podem fazê-lo com o intuito de permanecer; e de que morar é um ato estritamente ligado à constituição de um espaço adequado, livre e íntimo para a vida cotidiana; um ato que concorre para a construção da identidade e para o desenvolvimento da personalidade do sujeito, pois, em torno do ato de morar, normalmente se estabelecem relações e vínculos sociais fundamentais para a vida, tais como amizade e/ou a familiaridade com o ambiente em que se vive ${ }^{36}$."

Estas afirmações convergem com os temas postos em análise no capítulo anterior, tratando do Direito à Cidade. Vale observar que os conflitos fundiários centrais para a realização deste trabalho são coletivos, como bem coloca o pesquisador. São principalmente os casos coletivos e de baixa renda que necessitam a efetividade do princípio em pauta.

Não se busca afirmações indiscutíveis, visto que a pesquisa consiste apenas em assentamentos informais e casos coletivos. Entretanto, para demonstrar um panorama específico e prático da eficácia da função social da propriedade, cabe utilizar este recorte. Ressalta-se que na prática

\footnotetext{
${ }^{35}$ Ibid., p. 398.

${ }^{36}$ Ibid., p. 392-393.
} 
judicial, não distinto, o direito à moradia confronta com o direito de propriedade.

No artigo que apresenta a pesquisa de Martins de Abreu, ele ressalta que deve haver uma ponderação de direitos. Nem sempre o direito à moradia vai prevalecer quando confrontado com a preservação do meio ambiente, da ordem urbana ou da propriedade. Porém, não deve prevalecer uma postura de preterir as garantias relativas a tal direito ${ }^{37}$.

Durante a pesquisa, foi identificado que os conflitos fundiários coletivos tendem a ser judicializados através de ações civis públicas, reintegração de posse e de reivindicatórias. $\mathrm{O}$ pesquisador questiona a judicialização destes conflitos e se há uma legitimidade política para isso. O devido processo legal e a ampla defesa nem sempre se demonstram efetivos, quanto menos a função social da propriedade. Ele afirma, em seu artigo, que:

\begin{abstract}
“(...) principalmente as duas primeiras [ação civil pública e reintegração de posse], frequentemente, obtêm liminar de despejo forçado sem oitiva dos assentados, e, o mais grave, por vezes tramitam sem oferecer aos assentados ou a representantes que elejam participar do processo que os prejudica." 38
\end{abstract}

Para explicar o que afirma, João Maurício refere-se a julgados e destaca dois argumentos principais que tendem a se sobrepor ao direito à moradia e à participação dos réus no processo nos tribunais brasileiros. $\mathrm{O}$ primeiro é o dano à ordem ambiental ou urbanística; já o segundo, é relativo à constante numerosa lista no pólo passivo das ações, que tumultuaria o processo, bem como a dificuldade da citação individual e da identificação exata dos assentados ${ }^{39}$.

Assim, quando se fala em ineficácia da aplicação do Princípio da Função Social da Propriedade, ou não aplicação do mesmo, trata-se de uma análise não só da prevalência do direito de propriedade nos conflitos

\footnotetext{
${ }^{37}$ Ibid., p. 399

${ }^{38}$ Ibid., p. 400.

${ }^{39}$ Ibid., p. 402.
} 
fundiários privados judicializados. Há também ação negativa do Estado na omissão de realizar medidas relativas à regularização fundiária e ação positiva na tentativa de remoções e despejos forçados de propriedades de titularidade pública, sem observância da ampla defesa e do devido processo legal, em nome do interesse público.

Para ilustrar a prática dos tribunais do Rio de Janeiro, cabe destacar dois casos de tentativas de remoção de comunidades pelo Estado. Os casos de Vila União e Vila Canoas são distintos, mas demonstram uma postura do Estado de preterir a função social em prol do "interesse público", não só na administração, como também nos tribunais.

A comunidade de Vila União é localizada na Zona Oeste do Rio de Janeiro, na região de Curicica, em Jacarepaguá. É composta por mais de mil famílias e existe há mais de trinta anos. Em 1993 muitos ocupantes tiveram sua posse reconhecida no programa "Meu pé no chão", que pretendia a regularização fundiária da área pela via administrativa. Através do Programa "Morar Carioca" o município reconhece a consolidação do núcleo urbano informal.

Durante os megaeventos, no entanto, houve a realização das obras de construção da via transolímpica, que liga a Zona Oeste do Rio à Avenida Brasil. O plano de elaboração da via não contou com um diálogo com a comunidade, sendo mais de duzentas famílias removidas em nome do interesse público.

A comunidade de Vila Canoas, também na Zona Oeste, é um núcleo urbano informal que existe desde 1977, na Estrada das Canoas, em São Conrado. O Município, há mais de vinte anos, entrou com um processo para a remoção do núcleo urbano informal, alegando que seria destinada a uma escola, bem como parte da comunidade se encontrava em área de reserva florestal. O Decreto Municipal $\mathrm{n}^{\mathrm{o}} 30.40 / 2001$, no entanto, reconhece a comunidade, pretendendo modificar os padrões urbanísticos da área e 
reforçar os parâmetros de usos e ocupação do solo. A área também foi declarada Área de Especial Interesse Social (AEIS) ${ }^{40}$.

No caso em tela, o Estado pretende regularizar a área para valorizála no mercado imobiliário, o que demonstra que a função social, novamente, não é o objetivo principal do Estado.

\subsection{Tutelas Coletivas}

O Princípio da Função Social da Propriedade e sua não aplicação revelam, principalmente nas tutelas coletivas, questões estruturais do direito que também são entraves para sua eficácia. José Isaac Pilati, bem destaca que:

"O discurso corrente, em relação à Função Social da Propriedade é bem conhecido. (...) pesa sobre a propriedade uma hipoteca em favor do bem comum. E continua: não se trata de simples limitações ou restrições ao exercício do direito, ou de simples obrigações negativas, mas de imposições de deveres positivos, que integram a própria essência do direito subjetivo. O não-cumprimento da função social legitima a intervenção do Estado, que pode, inclusive, desapropriar a coisa, por interesse social (...)"41

Para o autor, no entanto, deve-se ir mais além, iniciando com uma crítica à dicotomia entre propriedade urbana e propriedade rural. Segundo Pilati, "vale dizer, a função social é coisa do proprietário, perante o Estado e seu poder de coerção (que raramente atua) ${ }^{42}$." Nesse sentido, enquanto a função social for tratada enquanto obrigação individual do proprietário, "perante a dependência do voluntarismo estatal, tão conveniente ao jogo da economia e dos altos interesses poderosos"43, não será viável sua eficácia. Segundo Pilati,

\footnotetext{
${ }^{40}$ As informações sobre os casos apresentados foram adquiridas durante estágio profissional no Núcleo de Terras e Habitação da Defensoria Pública do Estado do Rio de Janeiro. Os dois processos são Ações Civis Públicas acompanhadas pelo núcleo temático. Para mais informações consultar: DANTAS, Julia Rezende Toribio. Territórios Marginalizados, Direito à Moradia e o Comum. 2018.

${ }^{41}$ PILATI, José Isaac. Op. cit., p. 50

42 Ibid., p. 51.

${ }^{43}$ Ibid., p. 52.
} 
"Cumpre dar à função social eficácia jurídica e efetividade social. Este é o desafio da Esfinge ao jurista contemporâneo; cumpre-lhe dar à função social autonomia conceitual e status jurídico, que a coloquem no mesmo plano em que é tratado o direito subjetivo individual; colocando os interesses da Sociedade em tempo real, no agora, como diz Bobbio (ao verberar contra as normas programáticas, a propósito de outra mazela de ineficácia, que são os direitos sociais) ${ }^{44}$."

Buscando dar esta "eficácia jurídica e efetividade social", Pilati resgata elementos do Direito Romano. Ele sustenta que há uma urgente necessidade de rever as classificações dos bens jurídicos nos códigos civis, os conceitos de propriedade e soluções mais apropriadas às tutelas coletivas. Para ele, o Direito Romano traz possíveis respostas aos atuais problemas relativos à função social.

\subsubsection{O Direito Romano e a Função Social}

O ponto que Pilati levanta como resposta aos conflitos fundiários coletivos é a terceira categoria de bens, "que pertencem a toda a sociedade, ou seja, a cada um e todos os indivíduos, coletivamente, e dos quais ninguém pode dispor individualmente. Nem o Estado!"45

O direito brasileiro, atualmente, trata a propriedade de forma dicotômica, de acordo com sua titularidade, que é pública ou privada. Cabe ressaltar que a titularidade é pública, mas o uso e gestão são do Estado. No entanto, na Roma Clássica, havia uma categoria de bens que permitia a copropriedade dos patrimônios coletivos - ou comuns, como será debatido mais adiante. Esta categoria jurídica comportava a contemplação de bens que "eram de propriedade de todo o povo, de forma que ninguém podia deles dispor individualmente, só coletivamente (...). ${ }^{46,}$

No Direito Romano, a figura da res publicae compreendia uma copropriedade, sendo aplicadas regras distintas daquelas do direito privado.

\footnotetext{
${ }^{44}$ Ibid., p. 53.

${ }^{45}$ Ibid., p. 54.

${ }^{46}$ Ibid., p. 55.
} 
Esta é uma diferença importante, visto que a propriedade ainda é tratada nos parâmetros do direito privado. Isto porque a definição por titularidade já limita o acesso, torna privado. Mesmo que a titularidade seja pública, pertence ao Estado ${ }^{47}$. Nas palavras do autor:

"Com a elevação do Estado à condição de pessoa jurídica coroando todo um processo -, criou-se um buraco negro na classificação dos bens, pois o novo ente usurpou a categoria dos bens jurídicos coletivos, criando um vazio jurídico, que abre caminho ao novo modelo histórico, da propriedade moderna. Sem isso, não teria sido possível, aos interesses privados, apoderar-se daqueles espaços que não coadunariam com a apropriação privada; o Estado encarrega-se de fazê-lo, como pessoa distinta e com capacidade legitimadora ${ }^{48}$."

Nesse sentido, a dicotomia entre público e privado presente nos códigos civis, priva a sociedade do alcance aos bens públicos - os que deveriam ser comuns, ou coletivos. A introdução dos interesses difusos e da função social são uma tentativa de amenizar as consequências do modelo adotado. No entanto, como se vem demonstrando, não são soluções verossímeis para as questões pertinentes ao direito à moradia.

Os interesses coletivos, das coisas pertencentes a toda a sociedade, não têm uma tutela eficiente hoje. Pilati afirma que a apropriação do socialcoletivo pelo Estado é um dos principais motivos para a permanência da função social apenas no "plano do remendo". A busca pela efetividade da função social esbarra na propriedade moderna ${ }^{49}$.

\footnotetext{
${ }^{47} \mathrm{O}$ fato de a propriedade ser tutelada pela sua titularidade em de sua função limita seu acesso, independente da titularidade. Por isso, mesmo que a propriedade seja pública, o acesso não é universal. O Estado, na estrutura atual, é o titular do direito de propriedade. Assim, a gestão e o uso da propriedade são responsabilidade do Estado, que pode botar o interesse público acima do cumprimento da função social. Por isso, mesmo a titularidade sendo pública, o acesso é privado.

48 PILATI, José Isaac. Op. cit., p. 56.

${ }^{49}$ Ibid., p. 64.
} 


\section{O paradigma da dicotomia entre público e privado}

O debate sobre a função social da propriedade levanta um ponto relevante, que é a forma como a propriedade é tratada hoje.

"[A Função Social] é um princípio que afeta e vincula todo e qualquer poder que se exerça sob a égide da Constituição: privado (econômico, patrimonial, financeiro) ou público (político, administrativo, incluído o jurisdicional).

É princípio que atua na colisão de uns e outros destes poderes com os bens coletivos, ou seja, aqueles bens que não são do Estado, nem do particular, mas de todos e cada um de nós, em regime de co-propriedade e co-responsabilidade (saúde, educação, ambiente e assim por diante)

(...) a função social pode incidir sobre bem patrimonial, social, cultural e não apenas sobre a propriedade corpórea do Código Civil; não decorre do direito particular, mas da interferência deste em valores e interesses sociais fundamentais, dos quais o titular é também coproprietário ${ }^{50} . "$

\subsection{A Comissão Rodotá}

A Comissão Rodotá ocorreu em 2008, na Itália, no contexto da tentativa de impedir a privatização da gestão da água. Esta Comissão introduziu no Direito Civil Romano o debate sobre os bens imateriais e seu tratamento em tal ramo do direito.

Os debates sobre o tema abordaram a importância da funcionalidade dos bens, não só de sua titularidade. As conclusões de tal Comissão trouxeram à tona os princípios da Constituição Italiana, vinculando a função dos bens à satisfação dos direitos fundamentais e o interesse público. A intenção final, frisa-se, é a garantia de acesso universal aos bens essenciais à vida e à produção social. ${ }^{51}$

Ainda, propôs-se uma nova sistemática de bens públicos, que compreendem os bens de pertencimento público necessário, bens públicos

\footnotetext{
${ }^{50}$ Ibid., p. 64.

${ }^{51}$ ITÁLIA. RODOTÀ, Stefano. Commissione Rodotà: per la modifica delle norme del codice civile in materia di beni pubblici. 2007.
} 
sociais e bens frutíferos. Foi proposta também a criação de uma categoria de bens denominados bens comuns ${ }^{52}$.

Nas palavras de Stefano Rodotà, em entrevista,

"Eu, porém, diria que hoje é necessária uma reflexão ulterior, isto é, distinguir mais claramente os interesses proprietários dos interesses não proprietários. Existem interesses que não podem ingressar no mercado. Este é o ponto, este é o limite. Porque a idéia da função social da propriedade nasceu em uma situação na qual se dizia: "Eu reconheço que o direito de propriedade existe e quero relativizar seu caráter absoluto, e o faço com o instrumento da função social da propriedade". Não é que esta segunda consideração não fosse presente, porque a categoria das coisas extra commercium existia mesmo antes, mas hoje esta consciência, para mim, tornou-se mais forte. Há uma série de bens que devem ser mantidos fora do mercado: todos aqueles que são definidos como patrimônio comum da humanidade; toda uma série de bens que dizem respeito à saúde, ao ambiente, uma série de aspectos que interessa à dignidade pessoal. Para estes, não aplica-se o instrumento da função social, mas sim o instrumento que é estar "fora do mercado". 53

Rodotà ainda vai mais além, questionando quais limites o legislador pode impor ao proprietário. Para ele, uma questão importante é a participação de outros sujeitos que não apenas o proprietário e o legislador. Há casos em que a natureza do bem exige um debate mais amplo e plural. A função social deve ser tratada como procedimento legislativo, mas também como fato do procedimento administrativo. O Estado deve buscar a garantia da possibilidade de participação dos bens, além da exclusão dos bens comuns do mercado ${ }^{54}$.

\subsection{A potência dos espaços públicos}

Virgínia Totti Guimarães traz algumas contribuições sobre os comuns, a função social e o direito de propriedade. Para ela, é impossível a

\footnotetext{
52 JUNIOR, Eroulths Cortiano; KANAYAMA, Rodrigo Luís. Notas para um estudo sobre os bens comuns. Academia Brasileira de Direito Constitucional. Curitiba, 2016, n. 15, Jul.-Dez. P. 480-491, p. 485.

${ }^{53}$ RODOTÀ, Stefano. Entrevista com Stefano Rodotà. [Entrevista concedida a] Danilo Doneda. Roma. Revista Trimestral de Direito Civil, v. 3, n. 11, jul-set 2002, pp. 225-308.

${ }^{54}$ Ibid.
} 
garantia do direito à cidade e uma gestão mais justa da cidade sem uma correspondente limitação aos direitos de propriedade públicos e privados ${ }^{55}$. Para ela, ainda,

"Não há contradição entre considerar espaços públicos como bens comuns, entender o direito à cidade como um direito intrinsecamente ligado ao poder de decidir e viver a cidade e exigir-se do Estado, leia-se poder público, uma atuação interventiva em relação aos direitos individuais ou o próprio cumprimento da função social da propriedade. O Estado continuará existindo e deve exercer um papel relevante em relação a garantia do direito à cidade, por exemplo, por meio da imposição de limitações ao direito de propriedade, executando os instrumentos que estão postos à sua disposição, no sentido de concretizar os desejos e decisões dos habitantes da cidade." 56

Os espaços públicos são essenciais na tentativa de garantia do direito à cidade e da aplicação da função social. Justamente por isso, há disputas por esses locais, confrontando interesse público e social. Virgínia Totti Guimarães entende que estes espaços possuem dimensão (i) física, (ii) social e (iii) política. Em suas palavras:

"Em uma dimensão física, pode-se afirmar que os espaços públicos são abertos, gratuitos e sem restrições de acesso, em regra. São estatais ou destinados ao uso público. Podem voltar-se à promoção de lazer e a atividades socioculturais. Representam áreas livres, muitas vezes com funções ambientais, como a contribuição para manutenção das condições climáticas e proteção da biodiversidade. Relacionam-se à diminuição de problemas de saúde e qualidade de vida, na medida em que pode interferir na poluição do ar, geração de espaços não construídos etc.

$\mathrm{Na}$ perspectiva social e política, os espaços públicos podem representar uma possibilidade de integração e interação entre as pessoas. Estão relacionados à construção de espaços de cidadania e exercício democrático. E, embora estejam sempre vinculados a uma forte presença estatal, seja por meio da fiscalização ou regulação, dependem da prática social para sua própria definição. Pode-se aproximá-los dos bens comuns, enquanto bens fora de comércio ou impossíveis de serem transformados em mercadorias ${ }^{57}$."

\footnotetext{
${ }^{55}$ GUIMARÃES, Virgínia Totti. Direito à cidade, comuns urbanos e privatização de espaços públicos na Cidade do Rio de Janeiro: Os casos da Marina da Glória e do Campo de Golfe Olímpico. Orientador: Prof. Adriano Pilatti. 2016. 246 p. Tese (Doutorado em Direito) - Pontifícia Universidade Católica do Rio de Janeiro, Rio de Janeiro, 2016, p. 60.

${ }^{56}$ Ibid., p. 61.

${ }^{57}$ Ibid., p. 82.
} 
O que ocorre, por outro lado, é a transferência dos comuns urbanos, destes espaços públicos, para a iniciativa privada. Assim, estes bens passam a atender aos interesses do mercado, não mais ao interesse coletivo ou comum. Assim, cabe uma análise mais densa sobre os espaços públicos e seu potencial na efetivação da função social, bem como nos debates apresentados sobre os bens comuns.

"O espaço público urbano designa tanto um lugar na cidade destinado a usos comuns, como praças, ruas, parques urbanos, quanto uma dimensão da vida social e política, baseada no exercício da cidadania. Pode tratar do aspecto físico, enquanto local disponibilizado pelo Estado para utilização geral ou da apropriação social que dele se faz. Pode ser analisado sob o enfoque sociológico, antropológico, político, urbanístico, jurídico, dentre outros, e cada um destes campos com múltiplas abordagens ${ }^{58}$."

Alguns fatores relacionados à decadência dos espaços públicos são (i) uma lógica individualista exacerbada, (ii) a violência urbana, (iii) os condomínios privados, (iv) a cultura do medo e (v) o cercamento de praças e parques. A privatização dos espaços públicos reforça que há ainda uma falta de acesso e disponibilidade destes espaços ao atendimento de sua função social. Por isso, há estampada nas paisagens das cidades brasileiras a desigualdade socioterritorial que diferencia os indivíduos e limita o acesso aos direitos fundamentais ${ }^{59}$. Ainda, ressalta que há normas instituídas com o intuito de limitar o acesso e uso destes espaços, além de uma fiscalização "efetiva" dependendo de quem ocupa o espaço.

"Espaços públicos são materialidades que representam parcela do exercício democrático (ou potenciais deste exercício) e espaços de reivindicação de direitos fundamentais para manutenção da qualidade de vida digna nas cidades, aliados à diminuição das desigualdades sociais. Os espaços públicos refletem, ainda, a atual centralidade do consumo, transformando-os em mercadorias ou destinando-os a determinados setores sociais. No entanto, estes mesmos espaços públicos são apropriados socialmente por diferentes práticas e muitas diversas das

\footnotetext{
${ }^{58}$ Ibid., p. 84.

${ }^{59}$ Ibid., p. $85-90$
} 
propostas pelo poder público, tornando-se, assim, locais com potencial de politização (... $)^{60}$."

Aqui fica nítida a dialética apresentada no segundo capítulo do presente trabalho. O espaço é produto e produtor social, havendo disputas sociais e políticas pela função dos territórios ${ }^{61}$. "E, neste sentido, congela-se a dialética proposta por Lefebvre e Dom Mitchell entre a concepção e o uso do espaço ${ }^{62}$." Deve-se ressaltar que estas disputas pela função e uso dos espaços públicos são uma disputa pela eficácia da função social enquanto princípio constitucional e elemento componente do instituto da propriedade. Importantíssimo destacar o papel dos sujeitos da sociedade civil e dos movimentos sociais na disputa e resistência pelas funções dos territórios e das propriedades. Fica cada vez mais nítida a ausência do Estado na tentativa de dar uma funcionalização coerente aos espaços, privilegiando o interesse público e a expansão do mercado.

Os debates sobre o comum são essenciais na busca pela efetivação da função social, justamente por levantarem a categoria dos bens comuns e buscarem a funcionalização da propriedade. Ao privilegiar a função em detrimento da titularidade, apresenta uma grande possibilidade de avanço no que tange a concretização da função social na prática. Nas palavras de Virgínia Totti,

"Os espaços públicos expressam desafios e questionamentos que se relacionam diretamente à posição do Estado, tanto em seu caráter físico, que abrange a disponibilização estatal do espaço, como na regulação e apropriação social destes locais. Além disso, a produção social e não estatal, portanto, impassível de ser apropriada pelo público e privado, igualmente encontra-se presente neste debate. Neste sentido, verifica-se uma aproximação de pontos centrais debatidos pela teoria dos bens comuns, inclusive em sua dimensão urbana, que podem auxiliar no entendimento sobre a privatização de espaços públicos ${ }^{63}$."

\footnotetext{
${ }^{60}$ Ibid., p. 91-92.

${ }^{61}$ Importante resgatar aqui que são as forças de ordem próxima e distante - já mencionadas no presente trabalho -, que atuam o espaço de forma dialética, moldando de forma dinâmica os territórios. Ficam explícitas as disputas pelas funções que atendem as populações locais e o Estado/Mercado.

${ }^{62}$ GUIMARÃES, Virgínia Totti. Op. cit., p. 95.

${ }^{63}$ Ibid., p. 99.
} 


\subsection{A Teoria dos Comuns}

A teoria dos bens comuns tem contribuições de diversos autores, que buscam uma autonomia dos sujeitos perante o Estado e a garantia do acesso universal aos bens essenciais à vida - os bens comuns. Nomes importantes dentro deste tema são Elionor Ostrom, Silvia Federici, David Harvey, Antonio Negri, Michael Hardt, Christian Laval e Pierre Dardot.

\subsubsection{As contribuições de Negri e Hardt}

Negri e Hardt são autores que trouxeram grandes contribuições para o debate sobre os comuns. Eles analisam a estrutura da sociedade através de um prisma biopolítico, construindo a Teoria do Comum. Eles resgatam filósofos e teóricos para analisar os modos de produção, construindo novas concepções de conceitos de classe ${ }^{64}$ e uma proposta de disputa contra o modelo de propriedade e sociedade atual.

Em uma perspectiva de uma sociedade globalizada, explicam o que compreendem enquanto comum:

"By 'the common' we mean, first of all, the common wealth of the material world - the air, the water, the fruits of the soil and all nature's bounty (...). We consider the common also and more significantly those results of social production that are necessary for social interaction and further production, such as knowledges, languages, codes, information, and so forth ${ }^{65}$."

\footnotetext{
${ }^{64}$ Os autores utilizam o conceito de multidão para definir um novo conceito de classe. Tal conceito deriva de uma concepção de trabalho e de produção na lógica atual do capitalismo. A multidão se diferencia de povo, massa e população justamente por compreender as camadas exploradas pelo atual sistema. Por fazerem uma análise biopolítica da sociedade, compreendem a importância da pluralidade possível no dissenso. Dentro dessa concepção, a subjetividade dos indivíduos tem um papel essencial no processo de resistência às diversas formas de pilhagem.

${ }^{65}$ NEGRI, Antonio; HARDT, Michael. Commonwealth. Paperback. Harvard University Press, 2011. 434p. (p. viii)
} 
Os autores ainda reforçam a ideia da cidade enquanto catalisador de novas formas de lutas urbanas, sendo espaço de produção do comum. A cidade tem papel politizador - principalmente os espaços públicos, como já destacados - e potência de produção social do comum. ${ }^{66}$ Exatamente por essa potência, os espaços públicos e os demais comuns são alvos do que chamam de predação - processo que Ugo Mattei e Laura Nader ${ }^{67}$ conceituam como "pilhagem ${ }^{68, "}$

Como forma de resistência a este processo, Negri e Hardt ressaltam que é urgente uma ruptura com a dicotomia entre o público e o privado. Justamente por atuarem de forma conjunta na predação dos comuns, é necessário que a propriedade seja categorizada de acordo com sua funcionalidade, e não sua titularidade.

\subsubsection{As contribuições de Dardot e Laval}

Christian Laval e Pierre Dardot também trazem pontos importantes pra o debate sobre os comuns. Eles definem o comum, levando em conta as contribuições de diversos autores do tema. Nas palavras dos autores,

"o comum, ao menos no sentido de obrigação que todos impõem a si mesmos, não pode ser nem postulado como origem que deve ser restaurada, nem dado imediatamente no processo de produção, nem imposto de fora, do alto. É importante, acima de tudo, atentar para a última parte desta conclusão: a pretensa 'realização' do comum na forma de propriedade do Estado só pode ser a destruição do comum pelo Estado. Consequentemente, se, apesar de tudo, alguma coisa do comum sobreviveu nos subterrâneos da sociedade, foi às custas da resistência a

\footnotetext{
${ }^{66}$ GUIMARÃES, Virginia Totti. Op. cit., p. 100.

${ }^{67}$ MATTEI, Ugo e NADER, Laura. Pilhagem: Quando o Estado de Direito é ilegal. Trad. Jefferson Luiz Camargo. $1^{\text {a }}$ ed. São Paulo. Martins Fontes. 2013, pg. 17.

${ }^{68} \mathrm{O}$ processo de apropriação dos comuns é um dos pressupostos dos autores que estão sendo trabalhados. Para eles, o Estado e o Mercado atuam enquanto parceiros nos processos de predação dos comuns. A fase atual do capitalismo esgota a força de trabalho e os meios de vida, sendo necessário atualizar e reforçar as possibilidades de resistência ao processo de pilhagem. Para mais informações, ler a obra dos autores ou consultar as referidas pesquisas: DANTAS, Julia Rezende Toribio. Territórios Marginalizados, Direito à Moradia e o Comum. 2018 e DANTAS, Julia Rezende Toribio. A Privatização da CEDAE e os Comuns. 2017. Disponível em: < http://www.puc-rio.br/pibic/relatorio_resumo2017/relatorios_pdf/ccs/DIR/DIRJ\%C3\%BAlia\%20Dantas.pdf>.
} 
este apoderamento pelo Estado. (...) o termo 'comuns' ou a expressão 'bem(ns) comum(ns)' servem para traduzir lutas, práticas, direitos e formas de viver que se apresentam como contrários aos processos de privatização e formas de mercantilização que se desenvolveram a partir dos anos 1980. A palavra 'comum', como adjetivo ou substantivo, no singular ou no plural, começou a funcionar como bandeira de mobilização, palavra de ordem da resistência, fio condutor da alternativa ${ }^{69}$."

A ação conjunta do Estado e do Mercado dá origem ao que denominam "governança", em um contexto que definem como "segundo movimento de cercamento dos comuns". Tal governança carrega um novo conceito de poder que também supera a dicotomia entre o público e o privado. A partir dessa constatação, os autores introduzem um novo paradigma dos comuns. Nas palavras dos autores,

"O paradigma dos comuns define-se expressamente contra a expansão da lógica proprietária e mercantil com a qual o neoliberalismo é usualmente identificado. A acreditarmos em David Bollier essa 'pilhagem silenciosa' diz respeito a todos os comuns (...), entre os quais se encontram, ao lado dos recursos naturais e dos espaços públicos, o patrimônio cultural, as instituições educacionais e a comunicação. Esse movimento geral de cercamento seria comandado pelas grandes empresas, com apoio de governos submissos à lógica do mercado ${ }^{70}$."

\subsubsection{O comum e a Função Social}

As colaborações da teoria do comum para o debate sobre a eficácia da função social na garantia do Direito à Moradia são nítidas. Esta teoria colabora com a ruptura da barreira criada pelos excessos dos poderes e garantias da propriedade e busca retirar a tutela dos interesses comuns do monopólio do Estado.

"O Estado não pode dispor dos bens coletivos, em benefício de interesses privados, ou mesmo dele próprio, pelo simples fato de que não lhe pertencem. (...) E em face disso, pode-se afirmar que a função social, é

\footnotetext{
${ }^{69}$ DARDOT, Pierre; LAVAL, Christian. Comum: Ensaio sobre a revolução no século XXI. 1. ed. São Paulo: Boitempo, 2017. 647p. (p. 100-101).

${ }^{70}$ Ibid., p. 106.
} 
o princípio informador da tutela coletiva dos interesses ou valores coletivos - ou sociais fundamentais [ou comuns] - como direitos subjetivos da Sociedade e de cada cidadão ${ }^{71}$."

A ideia de apropriação dos espaços públicos buscando a garantia dos direitos fundamentais, bem como a proposta de funcionalização do direito de propriedade são essenciais para respaldar o Princípio da Função Social da Propriedade e sua aplicação nos conflitos fundiários.

"De uma maneira geral, os bens comuns permitem, entre sua estrutura e função, a realização dos direitos fundamentais. Eles ocupam já o dizia Garrett Hardin (2015) - uma posição central entre as categorias do jurídico e do político: os bens comuns são um instrumento político e constitucional para a satisfação direta das necessidades e dos direitos fundamentais ${ }^{72}$."

A tentativa de romper com a dicotomia entre o público e o privado tem como finalidade priorizar a funcionalidade do bem, independentemente de sua titularidade. Por isto,

“(...) ainda que se possa defender - ao menos num plano teorético - a idéia de bens sem propriedade (portanto, um lugar do não direito, em que certos bens seriam inapropriáveis por quem quer que seja, inclusive o Estado) ou bens de propriedade difusa (conceito de difícil construção), é certo que os bens comuns serão sempre titularizados. Eles podem pertencer ao Estado ou, mesmo, ao particular. O que neles importa é o acesso, e esse acesso é construído de tal maneira que será vedado seu uso exclusivo, com também sua comercialização: como estes bens estão voltados à satisfação das necessidades primárias da coletividade, e assim servem para efetivar os direitos fundamentais, sua vexata quaestio não é a da apropriação, mas do seu uso e funcionamento. Têm eles uma função natural, como pretendeu a Comissão Rodotá"73.

\footnotetext{
${ }^{71}$ PILATI, José Isaac. Op. cit., p. 66.

72 JUNIOR, Eroulths Cortiano; KANAYAMA, Rodrigo Luís. Op. cit., p. 487.

73 Ibid., p. 489.
} 


\section{O comum como instrumento de garantia do Direito à Moradia}

\subsection{As experiências no grupo Terras e Lutas ${ }^{74}$ e no Núcleo de Terras e Habitação ${ }^{75}$ (NUTH)}

Os temas da propriedade e de sua funcionalização para atender ao interesse comum se demonstraram relevantes principalmente a partir das experiências no grupo Terras e Lutas e no NUTH. Foi possível a oportunidade de compreender como, na prática, os temas debatidos nos capítulos anteriores são relevantes para a realidade que atuamos, bem como o potencial de mudança que essas reflexões carregam.

Cabe partilhar algumas das palavras de Maria Lúcia Pontes, Defensora Titular do NUTH, em entrevista ${ }^{76}$ :

"O legado foi esse, de começar uma crítica, um questionamento sobre o direito à cidade. (...) $\mathrm{O}$ legado foi de desmistificar o direito, (...) tratar o direito como uma coisa real, que a gente tem que se apropriar. Pelo menos uma sementinha, que ainda tem que germinar."

\subsubsection{As colaborações do Terras e Lutas}

O grupo interdisciplinar de extensão Terras e Lutas atua nas dimensões urbana e rural da luta pela terra e pelo direito à moradia. Buscase, na dimensão agrária, a produção "comum de novos conhecimentos sobre a realidade agrária, a preservação do meio ambiente e da memória em áreas

\footnotetext{
${ }^{74}$ Carinhosamente chamado Terras e Lutas, o Grupo Direitos em Movimento: Territórios e Comunidades é um grupo de extensão vinculado ao Núcleo de Estudos Constitucionais da PUCRio. Participação no grupo com início em 2015.1.

75 Trata-se do núcleo temático da Defensoria Pública do Estado, chamado Núcleo de Terras e Habitação (NUTH), com atribuição para atuar nos casos fundiários que tenham ao menos dez núcleos familiares envolvidos. Estágio de dois anos.

${ }^{76}$ PONTES, Maria Lúcia. [Entrevista concedida a] Manuela de Carvalho Meireles. Megaeventos e direito à moradia adequada: obstáculos enfrentados hoje na efetividade deste direito humano fundamental. Orientador: Ricardo Nery Falbo. 2013. 136 f. Monografia (Graduação de Direito) UERJ, Rio de Janeiro, 2013.
} 
de reforma agrária, e a dimensão político-jurídica de todas essas questões $^{77,}$.

Ainda tratando do espaço agrário, são realizadas atividades de vivência $^{78}$ em parceria com o MST (Movimento dos Trabalhadores sem Terra). "Espera-se com isso contribuir para a superação de preconceitos e estereótipos acerca dessas comunidades rurais, ainda existentes nos ambientes urbanos ${ }^{79}$."

Nas perspectivas de efetivação do Direito à Cidade, o grupo atua em conjunto com comunidades parceiras ${ }^{80}$, buscando atender demandas apresentadas por elas. Vale destacar, nesse sentido, a construção com o a Associação de Moradores do Horto (AMAHOR). O Horto Florestal é uma comunidade ameaçada de remoção desde os anos 1980. Tal parceria resultou em mutirões de assessoria jurídica ${ }^{81}$ para atender aos moradores, bem como uma articulação para melhor estrutura de defesa dos mesmos ${ }^{82}$.

\subsubsection{As colaborações do NUTH}

O NUTH é um núcleo temático da Defensoria do Estado do Rio que tem atribuição para assistir os conflitos fundiários que envolvam a

\footnotetext{
77 PILATTI, Adriano; GUIMARÃES, Virgínia Totti; QUINTANS, Mariana Trotta Dallalanas; PINTO, Paula Máximo de Barros; BARROUIN, Nina. SEMINÁRIO DIREITOS, PESQUISA E MOVIMENTOS SOCIAIS, 7., 2018, Rio de Janeiro. Estágio Interdisciplinar em Vivência: Direitos, Desenvolvimento Rural Sustentável e Memória da Reforma Agrária no Assentamento Roseli Nunes (Piraí, RJ). Rio de Janeiro: Universidade Federal do Rio de Janeiro, 2018. 20p., p. 7

${ }^{78}$ São atividades realizadas pelo grupo, permitindo a experiência de troca de saberes entre os estudantes universitários e assentados rurais. Para mais informações, referir-se ao artigo supracitado, que foi produzido coletivamente por integrantes do Terras e Lutas.

79 PILATTI, Adriano; GUIMARÃES, Virgínia Totti; QUINTANS, Mariana Trotta Dallalanas; PINTO, Paula Máximo de Barros; BARROUIN, Nina. Op. Cit., p. 7.

${ }^{80}$ Cabe destacar aqui que além da parceria com o Horto, o grupo já atuou junto à Vila Autódromo e à Defensoria Pública, bem como à Comunidade Chapéu Mangueira. No primeiro caso, o grupo atuou na tentativa de impedir a remoção do local no contexto dos megaeventos. Já no segundo, o grupo realizou um mutirão de assessoria jurídica para auxiliar os moradores a reivindicar seus direitos em defesa às tarifas abusivas da Light (fornecimento privado de luz).

${ }^{81}$ Os mutirões foram atividades organizadas conjuntamente pelo grupo, pelo advogado de defesa e pela representação dos moradores. Consistiram em sete tardes em que os integrantes do grupo, o advogado de defesa e colaboradores compareceram à comunidade oportunizando aos moradores uma assessoria jurídica mais subjetiva, com atendimentos individuais explicando o andamento do processo de cada morador presente.

${ }^{82}$ Atualmente o advogado de defesa da comunidade trabalha em parceria com o Terras e Lutas e o Núcleo de Prática Jurídica (NPJ) da PUC-Rio.
} 
representação de dez ou mais núcleos familiares. Ao longo de dois anos de estágio profissional, participando de processos judiciais, administrativos e políticos, foi possível ter um panorama prático de como a luta pela moradia acontece no Rio de Janeiro, em todas estas esferas.

Também foi possível a participação em debates sobre o planejamento da cidade e sobre as legislações atuais e antigas de regularização fundiária ${ }^{83}$. Ainda, principalmente, exigiu contatos diretos com os moradores das comunidades ${ }^{84}$. Os processos se tornam mais subjetivos e contempla-se uma perspectiva de quem é afetado diretamente pela morosidade do Estado, no que tange a garantia ao Direito à Moradia.

Ao ter a possibilidade - tanto no NUTH, quanto no Terras e Lutas de compartilhar das angústias da insegurança da posse e das alegrias de cada conquista relativa à concretização da garantia de uma moradia digna, tornou-se imprescindível ao menos tentar buscar soluções para as questões da moradia.

\subsection{Comum e a Moradia}

Após todo o exposto, é irreconhecível a potência do comum na concretização da garantia ao Direito à Moradia e à Função Social da Propriedade. O comum - enquanto ferramenta do Direito Civil e enquanto teoria -, traz fundamentação teórica e uma proposta de práxis que têm a possibilidade de munir o Direito de instrumentos necessários para uma efetivação de fato do Direito à Cidade e do acesso ao Direito, como um todo $^{85}$.

\footnotetext{
${ }^{83}$ Foi possível, ao longo do estágio, a participação em organização e participação de eventos e projetos da DPGE, bem como debates de movimentos sociais, academia e administração pública sobre o planejamento da cidade.

${ }^{84}$ A dinâmica do NUTH exige contato direto com os assistidos, ao passo que a defesa é coletiva. São realizadas reuniões coletivas no núcleo, nas comunidades/ocupações, bem como atendimento individual presencial ou por telefone sobre os andamentos processuais.

${ }^{85} \mathrm{Na}$ bibliografia selecionada para a realização do presente trabalho é possível verificar que o acesso ao direito é ainda bastante limitado apesar da Defensoria e da gratuidade de justiça.
} 
Apesar de a Função Social compor o conceito de propriedade, ainda é evidente que há barreiras jurídicas, sociais e culturais para que este entendimento alcance à realidade de quem vive as precariedades causadas pela inacessibilidade do Direito à Moradia. É urgente uma atualização do direito de propriedade que compreenda o interesse comum, não só enquanto garantia jurídica, mas como direito de acesso universal.

As cidades e o campo reproduzem os incontestáveis contrastes dos privilégios de quem é sustentado pelo trabalho dos que são renegados e precarizados. O Direito como ferramenta de transformação e de mudanças deve buscar ampliar cada vez mais o acesso a uma vida digna, e o comum busca, nas brechas, garantir direitos. O Direito não pode ser apenas instrumento de manutenção de estrutura.

"Para ter eficácia jurídica, a concepção de função social deve romper esse casulo da propriedade potestativa - nas mãos e à mercê do proprietário [titular] - e exteriorizar-se como bem jurídico autônomo coletivo, que é e representa, ante o particular e o próprio Estado (pessoa jurídica).

Em outras palavras, a autonomia do bem coletivo [ou comum] e sua equiparação ao direito subjetivo do proprietário são vitais à função social e importam no reconhecimento da tutela respectiva, que se desloca do monopólio dos agentes estatais para a Sociedade, sem monopólios.

Deve-se ter claro, portanto, que a função social pode incidir sobre bem patrimonial, social, cultural e não apenas sobre a propriedade corpórea do Código Civil; não decorre do direito particular, mas da interferência deste em valores e interesses sociais fundamentais, dos quais o titular é também co-proprietário." ${ }^{86}$

O fortalecimento da funcionalização dos direitos, principalmente o de propriedade, é um avanço importante no que diz respeito à tentativa de garantia da Função Social. A Comissão Rodotà, ao tentar criar a categoria dos bens comuns, buscou trazer para o âmbito do direito civil a funcionalização do direito de propriedade.

Os instrumentos coletivos de propriedade e de legitimação de posse são importantes brechas para o comum. Por serem coletivos, tendem a

\footnotetext{
${ }^{86}$ PILATI, José Isaac. Op. cit., p. 65.
} 
carregar, inerentemente, uma função social. Por exemplo, a legitimação de terras quilombolas, de comunidades tradicionais, de comunidades indígenas e as expropriações para fins de reforma agrária carregam em si uma função social. Ressalta-se que aqui que todos os exemplos são considerados comuns, latu sensu.

"A par dos bens públicos e privados, é necessário acrescentar a categoria dos bens sociais ou coletivos [comuns, no presente trabalho]; aqueles que pertencem a todas as pessoas e dos quais ninguém - nem mesmo o Estado e principalmente ele - pode dispor individualmente. Trata-se dos bens como [moradia,] ambiente, saúde, enfim, os direitos sociais fundamentais garantidos pela Constituição da República.

A função social submete, hierarquicamente, a esses bens coletivos ou sociais todo e qualquer poder exercido na Sociedade, seja a título de propriedade em sentido amplo - qualquer direito patrimonial - seja o poder político (função social do Estado).

(...) Função social não se confunde com solidariedade social. A função social não está dentro da propriedade individual; ao contrário, é uma exterioridade em relação a ela, constituindo direito autônomo da coletividade". 87

Apesar de todos os contrassensos relativos à Função Social da Propriedade, é possível, através dos comuns, buscar uma concretização de um princípio que ainda não se demonstra capaz de sanar os gritantes contrastes sociais do país. Para isso, é imprescindível que se rompam algumas dicotomias, como a do interesse público ou social e a do público ou privado. O interesse comum, no contexto de precarização atual, deveria ser prioridade; o acesso universal aos bens comuns deveria ser garantido urgentemente.

Assim, a introdução dos bens comuns enquanto categoria do Direito Civil é urgente. O contexto de predação dos comuns e de inacessibilidade do direito exige uma proteção concreta destes bens nos ordenamentos jurídicos. A realidade e as dinâmicas da cidade comprovam que a dicotomia do público e do privado já foi superada fora do direito. Independentemente de titularidade, os espaços são ocupados para fins de moradia. É papel do

\footnotetext{
${ }^{87}$ PILATI, José Isaac. Op. cit., p. 67.
} 
judiciário e do legislativo entenderem que a questão de que se trata é urgente.

Já em nível constitucional, é imprescindível o reconhecimento do comum enquanto interesse do Estado. A garantia do interesse comum é uma forma de impedir que o interesse público ou privado prevaleça sobre o interesse social. A Função Social da Propriedade, enquanto princípio, não é capaz, sozinha, de romper com a dicotomia do público e do privado. É necessário que haja uma proteção do comum para que o Princípio da Função Social seja eficaz, na medida em que não possa ser afastado em nome do interesse público. 


\section{Conclusões}

Inicialmente, buscou-se uma discussão sobre o instituto da propriedade e as modificações que o princípio da função social e a Constituição de 1988 trouxeram. A partir de uma análise da evolução do instituto da propriedade no Brasil, foi possível verificar que, atualmente, há múltiplas modalidades de propriedades que devem todas atender a uma função social. O direito de propriedade não é mais um direito fundamental individual absoluto, visto que só é reconhecida a propriedade que se adeque à condição do cumprimento da função social. Foi apresentado um longo debate sobre o tratamento legislativo da propriedade e da função social, buscando evidenciar que tal instituto ainda precisa ser reformulado.

O debate sobre Direito à Cidade é fundamental para compreender as dinâmicas das cidades e a realidade social da falta do acesso à moradia e aos demais direitos que a vida urbana compreende. Foi demonstrado que o déficit habitacional nos centros urbanos brasileiros é preocupante e que as legislações atuais sobre moradia urbana e rural não são aplicadas ou não são direcionadas às demandas das moradias informais. A postura que o Estado vem tomando é de higienização e militarização destes espaços, buscando atender demandas do mercado imobiliário e excluir dos territórios cada vez mais as classes trabalhadoras - urbana e rural -, principalmente os trabalhadores informais.

A realidade judicial que se apresenta com relação à moradia hoje é da prevalência do título de propriedade e da desconsideração da posse com função social. As ações coletivas não são tuteladas pela função social nem pela ampla defesa e o devido processo legal. Os conflitos são decididos no judiciário, sem a devida participação dos principais afetados pelas decisões. Liminares são concedidas sem levar em consideração a precariedade da moradia nas metrópoles e no campo. A realidade do judiciário e da administração pública não compreendem as especificidades e dinâmicas dos territórios que não integram a "cidade formal". 
$\mathrm{Na}$ intenção de avançar nos debates sobre planejamento urbano e reforma agrária, torna-se necessário trazer a perspectiva do comum e da ruptura da dicotomia entre público e privado. As dinâmicas das ocupações dos territórios ocorrem independentemente da titularidade, sendo imprescindível reconhecer as novas formas de propriedade nos ordenamentos jurídicos. A Função Social da Propriedade é um instrumento importante nesse reconhecimento, mas esta dicotomia precisa ser superada para que tenha uma eficácia real.

A teoria do comum trata de uma análise da tentativa de apropriação e atuação do Estado e do mercado nos referidos territórios, entendendo que as ferramentas do Direito são de uso do Estado. Assim, além de fornecer o comum como instrumento do direito civil e constitucional, demonstra que o Estado não pode ter o monopólio da defesa dos comuns, visto que atua para favorecer o mercado. É nesse sentido que é importante compreender os limites da aplicação da função social. O comum não só é uma teoria, mas um incentivo à reflexão de que a defesa dos comuns não será feita pelo Estado, mas pela multidão - ou pelo dissenso de subjetividades. Aqui é essencial a perspectiva da funcionalização da propriedade e a co-ação de diversos setores da sociedade enquanto potências de instituição do comum, questionando o papel do Estado e resistindo às tentativas de pilhagem.

As experiências no NUTH e no Terras foram essenciais para entender, na prática, como todas estas teorias se revelam potentes na concretização do direito à moradia. O debate jurídico sobre a moradia é essencial, entendendo como pressuposto que a função social não tem demonstrado eficácia. Assim, um caminho possível para a eficácia deste instrumento é a introdução dos comuns no direito brasileiro. As dinâmicas sociais já delineiam a ruptura da dicotomia da titularidade pública ou privada, então cabe aos aplicadores e formuladores do Direito compreender estas dinâmicas e introduzi-las na práxis jurídica.

A advocacia popular, a assessoria jurídica popular, as universidades e a Defensoria têm um papel importante na concretização imediata do 
direito de morar. No entanto, frente à ineficácia dos instrumentos jurídicos e em face de um judiciário conservador, os meios formais de concretização do Direito à Moradia são limitados e extremamente prolongados. É crucial romper com a dimensão absoluta do direito de propriedade e pensar em sua funcionalização. Para isto, é necessária a introdução do comum nos ordenamentos jurídicos como forma de fazer prevalecer a Função Social, permitindo que o interesse público - da pessoa jurídica do Estado - seja afastado em nome do comum.

Por se tratar de uma realidade complexa, não se pode limitar o debate a um plano ou teórico ou prático, mas tentar unir estes campos à realidade social. O Direito brasileiro precisa ser urgentemente reformado, regulando os tipos de propriedades de acordo com suas especificidades e compreendendo que o interesse do Estado ou o interesse público são divergentes do interesse comum.

Ao romper com a dicotomia entre o público e o privado e privilegiar a funcionalização das propriedades, permite uma ampliação do acesso à moradia. O público, como já mencionado, por representar uma pessoa jurídica, representa seus interesses. Assim, não é possível contar com que o interesse do Estado seja privilegiar a moradia enquanto função social dos imóveis públicos, por exemplo. Ainda, não se pode contar com a boa vontade dos governos e das instituições públicas no que tange a concretização de direitos. A luta é para que os direitos sejam mais presentes que a violência do Estado. Enquanto o direito for só "conveniente", não se poderá falar em justiça, ou tutela dos interesses individuais ou coletivos pelo Estado.

A função social da propriedade e o comum oferecem alternativas de justiça social, de concretização do direito à moradia e dos direitos da cidade. Que seja possível, ao menos na Academia, ter a esperança de que o Direito seja um instrumento de mudança. Que seja possível, nos nossos caminhos, lutar contra as injustiças e tentar buscar soluções, não só para o futuro, mas para agora. 


\section{Bibliografia}

ABREU, João Mauricio Martins de. A construção histórica do modelo proprietário no Brasil: uma hipótese sobre o direito à moradia. Revista Direito e Práxis, Rio de Janeiro, v. 5, n. 8, p. 213-239, 2014.

ABREU, João Maurício Martins de. A moradia informal no banco dos réus: discurso normativo e prática judicial. Revista de Direito FGV, São Paulo, 2011, p. 391-415.

AGAMBEN, G. Homo sacer: o poder soberano e a vida nua I. Belo Horizonte: Ed. da UFMG, 2002.

BALDEZ, Miguel Lanzelotti. Solo urbano. Reforma, propostas para a Constituinte. Revista da Procuradoria Geral do Estado do Rio de Janeiro. Vol. 38. 1986.

BRASIL. Constituição (1824). Constituição Política do Império do Brasil. Rio de Janeiro, 1824.

BRASIL. Constituição da República Federativa do Brasil. Brasilia, 1988.

BRASIL. Decreto-Lei no 591, de 06 de Julho de 1992. Promulga o Pacto Internacional sobre Direitos Sociais, Econômicos e Culturais.

BRASIL. Estatuto da Cidade: Lei 10.257/2001 que estabelece diretrizes gerais da política urbana. Brasília, Câmara dos Deputados, 2001, 1a Edição.

BUROCCO, L. A cultura e a cidade como bem comum: os casos italianos do Teatro Valle Occupato em Roma e $\mathrm{M}^{\wedge} \mathrm{C}^{\wedge} \mathrm{O}$ em Milão. Lugar Comum, n. 43 , p. 129-147.

CASTELS, Manuel. A questão urbana. trad. bras. 1a reimpressão. Ed. Paz e Terra, 2000.

DANTAS, Julia Rezende Toribio. A Privatização da CEDAE e os Comuns. 2017.

DANTAS, Julia Rezende Toribio. Territórios Marginalizados, Direito à Moradia e o Comum. 2018. Disponível em: <http://www.pucrio.br/pibic/relatorio_resumo2018/relatorios_pdf/ccs/DIR/DIRJulia_Rezende_Toribio_Dantas.pdf $>$.

DARDOT, Pierre; LAVAL, Christian. Comum: Ensaio sobre a revolução no século XXI. 1. ed. São Paulo: Boitempo, 2017. 647p. 
DECLARAÇÃO UNIVERSAL DOS DIREITOS HUMANOS. Assembleia Geral das Nações Unidas em Paris. 10 dez. 1948.

ESPOSITO, Roberto. A Teoria do Bem Comum. La Republica. Roma. 01 jun. 2015. Disponível em: <http://www.ihu.unisinos.br/noticias/543227-ateoria-do-bem-comum-artigode-roberto-esposito>. Acesso em: 10/07/2016.

EVARISTO, Conceição. Becos da Memória. 3. ed. Rio de Janeiro: Pallas, 2017. 198 p. ISBN 978-85-347-0520-2.

EVARISTO, Conceição. Olhos D'água. 1. ed. Rio de Janeiro: Pallas: Fundação Biblioteca Nacional, 2016. 116 p. ISBN 978-85-347-0520-2/97885-333-0739-1.

Falcão, Joaquim. Invasões urbanas, conflitos de direito de propriedade. Revista Forense, n. 300,1987.

FERNANDES, Edésio. A nova ordem jurídico-urbanística no Brasil. In: FERNANDES, Edésio; ALFONSIN, Betânia. Direito urbanístico: estudos brasileiros e internacionais. Belo Horizonte: Del Rey, 2006.

FUINI, L. L. O Território em Rogério Haesbaert: concepções e conotações. Geografia, Ensino e Pesquisa v. 21, n. 1, p. 19-29, 2017.

FUNDAÇÃO JOÃO PINHEIRO. Déficit Habitacional no Brasil 2015. Estatística \& Informações 6: Demografia e Indicadores Sociais. Belo Horizonte, 2018.

GUIMARÃES, Virgínia Totti. Direito à Cidade e Direitos na Cidade: Integrando as perspectivas social, política e jurídica. Revista de Direito Da Cidade, Rio de Janeiro, v. 09, n. 2, p. 626-665, 2018.

GUIMARÃES, Virginia Totti. Direito à cidade, comuns urbanos e privatização de espaços públicos na Cidade do Rio de Janeiro: Os casos da Marina da Glória e do Campo de Golfe Olímpico. Orientador: Prof. Adriano Pilatti. 2016. 246 p. Tese (Doutorado em Direito) - Pontifícia Universidade Católica do Rio de Janeiro, Rio de Janeiro, 2016.

GUIMARÃES, Virgínia Totti; PINTO, Paula Máximo de Barros. Racismo ambiental e aplicação diferenciada das normas ambientais: uma aproximação necessária entre os casos da Comunidade do Horto Florestal e do Condomínio Canto e Mello (Gávea/RJ), 16p. Rio de Janeiro, 2018.

HAESBAERT, Rogério. Viver no Limite: território e multi/transterritorialidade em tempos de in-segurança e contenção. Rio de Janeiro: Bertrand Brasil, 2014. 
ITÁLIA. RODOTÀ, Stefano. Commissione Rodotà: per la modifica delle norme del codice civile in materia di beni pubblici. 2007.

JUNIOR, Eroulths Cortiano; KANAYAMA, Rodrigo Luís. Notas para um estudo sobre os bens comuns. Academia Brasileira de Direito Constitucional. Curitiba, 2016, n. 15, Jul.-Dez. P. 480-491.

JUNIOR, Nelson Saule. Estatuto da Cidade e o Direito à Moradia. In: JUNIOR, Nelson Saule. A proteção jurídica da moradia nos assentamentos irregulares. Porto Alegre: Sergio Antonio Fabris Editor, 2004. cap. VI, p. 205-249.

JÚNIOR, Nelson Saule. O Direito à Cidade como paradigma de cidades justas, democráticas e sustentáveis. In: Roberto B. Dias da Silva. (Org.). Direito Constitucional Temas Atuais. 1ed. São Paulo: Editora Método, 2007, v. 01, p. 169-210.

LEFEBVRE, Henri. A Revolução Urbana. Belo Horizonte: EDUFMG, 2004

LEFEBVRE, Henri. O Direito à Cidade. $1^{a}$ ed. São Paulo: Moraes, 1991.

MACHADO, Ivja Neves Rabelo. A eficácia dos direitos sociais Conteudo Juridico, Brasilia-DF: 15 nov 2019. Disponivel em: https://conteudojuridico.com.br/consulta/Artigos/42267/a-eficacia-dosdireitos-sociais. Acesso em: 15 nov 2019.

MATTEI, Ugo e NADER, Laura. Pilhagem: Quando o Estado de Direito é ilegal. Trad. Jefferson Luiz Camargo. $1^{\text {a }}$ ed. São Paulo. Martins Fontes. 2013.

MBEMBE, Achille. Necropolítica. São Paulo: N-1 edições, 2018, 80p. ISBN 9788566943504.

MEIRELES, Manuela de Carvalho. Megaeventos e direito à moradia adequada: obstáculos enfrentados hoje na efetividade deste direito humano fundamental. Orientador: Ricardo Nery Falbo. 2013. 136 f. Monografia (Graduanda de Direito) - UERJ, Rio de Janeiro, 2013.

MENDONÇA, Rafael da Mota. A Transferência de Propriedade como Novo Modelo da Regularização Fundiária: a Legitimação Fundiária e a Legitimação de Posse. In: FERNANDES, Arícia Correias (Org.). Direito da Regularização Fundiária Urbana Sustentável. Juiz de Fora: Editar, 2018. P. 259-284. 
NABACK, C. P. de A. Remoções biopolíticas: o habitar e a resistência da Vila Autódromo. Rio de Janeiro, 2015. Dissertação (Mestrado) - PUC-Rio.

NEGRI, Antonio; HARDT, Michael. Commonwealth. Paperback. Harvard University Press, 2011. 434p.

OLIVEIRA, Álvaro Borges de; ROSSETTO, Danielle Cristina. A Propriedade como Direito (Não) Fundamental na Constituição Brasileira. Revista do Direito UNISC, Santa Cruz do Sul, n. 37, jan/jun. 2012.

OLIVEIRA, Daniel Almeida de . O Direito da Cidade no Direito e nas questões sociais: limites, possibilidades e paradigmas. In: Coutinho, Ronaldo do Livramento; Bonizzato, Luigi. (Org.). Direito da Cidade: novas concepções sobre as relações jurídicas no espaço social urbano.. 1ed.Rio de Janeiro: Lumen Juris Editora, 2007, v. 1.

PILATI, José Isaac. Propriedade e função social na pós-modernidade: função social e tutelas coletivas: contribuição do direito romano a um novo paradigma. Revista Sequência, n. 50, p. 49-69, jul. 2005.

PILATTI, Adriano; GUIMARÃES, Virgínia Totti; QUINTANS, Mariana Trotta Dallalanas; PINTO, Paula Máximo de Barros; BARROUIN, Nina. SEMINÁRIO DIREITOS, PESQUISA E MOVIMENTOS SOCIAIS, 7., 2018, Rio de Janeiro. Estágio Interdisciplinar em Vivência: Direitos, Desenvolvimento Rural Sustentável e Memória da Reforma Agrária no Assentamento Roseli Nunes (Piraí, RJ). Rio de Janeiro: Universidade Federal do Rio de Janeiro, 2018. 20p.

PONTES, Maria Lúcia. [Entrevista concedida a] Manuela de Carvalho Meireles. Megaeventos e direito à moradia adequada: obstáculos enfrentados hoje na efetividade deste direito humano fundamental. Orientador: Ricardo Nery Falbo. 2013. 136 f. Monografia (Graduação de Direito) - UERJ, Rio de Janeiro, 2013.

ROCHA, Cristiano Silva da; VITTE, Claudette. O espaço dos pobres e a regularização fundiária: segregação em favelas de países da América do Sul. Observatório geográfico América Latina, São Paulo, p. 1-15, 2007. Disponível em: <http://observatoriogeograficoamericalatina.org.mx/egal12/Geografiasocioe conomica/Geografiaurbana/151.pdf>. Acesso em: 18 jun. 2019.

RODOTÀ, Stefano. Entrevista com Stefano Rodotà. [Entrevista concedida a] Danilo Doneda. Roma. Revista Trimestral de Direito Civil, v. 3, n. 11, jul-set 2002, pp. 225-308.

SANTOS, Boaventura Sousa. Pela mão de Alice. O social e o político na pósmodernidade. 9a ed., Cortez Editora, 2003. 
SANTOS, José Marinho Séves; DANTAS, Julia Rezende Toribio. Megaeventos e o Comum. 2016. Disponível em: <http://www.pucrio.br/pibic/relatorio_resumo2016/relatorios_pdf/ccs/DIR/DIR-José Santos e Julia Dantas.pdf>. Acesso em: 20 jul. 2017.

SILVA, José Afonso da. Curso de Direito Constitucional Positivo. 24. Ed. São Paulo: Malheiros Editores Ltda., 2005. 924 p. ISBN 8574206326.

TEPEDINO, Gustavo; SCHREIBER, Anderson. A Garantia Da Propriedade No Direito Brasileiro. Revista da Faculdade de Direito de Campos, Ano VI, Nº 6 - Junho de 2005.

WERNECK, Augusto. Função Social da Cidade. Plano Diretor e Favelas. A Regulação Setorial nas Comunidades Populares e a Gestão Democrática da Cidade. In:___ Direito da Cidade: Novas concepções sobre as relações jurídicas no espaço social urbano. Rio de Janeiro: Lumen Juris, 2007. 
